\title{
Evaluation of Continuous Lactation and Increased Milking Frequency on Milk Production and Mammary Cell Turnover in Primiparous Holstein Cows
}

\author{
A. C. Fitzgerald, ${ }^{*}$ E. L. Annen-Dawson, $†$ L. H. Baumgard, $\ddagger$ and R. J. Collier ${ }^{1}$ \\ *Monsanto Company, St. Louis, MO 63167 \\ †Oord Dairy, Sunnyside, WA 98944 \\ ‡Department of Animal Sciences, University of Arizona, Tucson 85721
}

\begin{abstract}
We hypothesized that early-lactation increased milking frequency, in combination with bovine somatotropin (bST), would improve milk yield in continuously milked (CM) primiparous glands through greater mammary epithelial cell (MEC) function, proliferation, and reduced apoptosis (cell turnover). Primiparous cows were randomly assigned to a $2 \times 2 \times 2$ factorial with a splitplot design to either a continuous bST $(+b S T, n=4)$ or no bST $(-\mathrm{bST}, \mathrm{n}=4)$ treatment throughout the study. Within each animal, udder halves were randomly assigned to either a CM or a 60-d dry period (control). During late gestation, CM glands were milked twice daily until calving or until spontaneous dry-off. At calving, cows were milked either twice or 4 times daily and udder-half milk yield was recorded until $30 \mathrm{~d}$ postpartum. Mammary biopsies were conducted on $-19 \pm 13$, $-8 \pm 6,+2,+7$, and $+20 \mathrm{~d}$ relative to calving. Postpartum milk yield was reduced in CM udder halves. Reduced milk yield in CM half udders from cows administered bST and milked 4 times daily was $35 \%$ compared with $65 \%$ in CM half udders in cows not provided bST and milked twice daily. Proliferation of MEC tended to be greater in control vs. CM tissue at $8 \pm 6 \mathrm{~d}$ prepartum. Mammary epithelial cell proliferation was greater during the prepartum period $(\mathrm{d}-19,-8)$ compared with postpartum time points $(\mathrm{d} 2,7,20)$. Apoptosis of MEC was not affected by dry period length, but was elevated during the first $7 \mathrm{~d}$ postpartum compared with levels measured at $-19,-8$, and $20 \mathrm{~d}$. Bovine somatotropin did not alter MEC turnover in primiparous CM or control glands. The use of increased milking frequency and bST alleviated, but did not prevent, reductions in milk yield of CM primiparous cows.
\end{abstract}

Key words: continuous milking, apoptosis, bovine somatotropin, increased milking frequency

Received April 16, 2007.

Accepted August 24, 2007.

${ }^{1}$ Corresponding author: rcollier@ag.arizona.edu

\section{INTRODUCTION}

A dry period (DP) of $60 \mathrm{~d}$ has traditionally been used to obtain maximal milk yield in the subsequent lactation, whereas a DP of less than $40 \mathrm{~d}$ is thought to reduce subsequent milk production by 5 to $15 \%$ (Remond et al., 1997; Bachman and Schairer, 2003). These reductions in milk yield are believed to be due to reduced functionality of the mammary epithelial cells (MEC), possibly associated with reduced cell turnover (Swanson et al., 1967; Capuco et al., 1997; Annen et al., 2007). Management practices that are known to improve functionality and possibly cell turnover, such as bST and increased milking frequency (IMF; Annen et al., 2004b; Collier et al., 2005), might ameliorate the effects of reduced DP length. In fact, bST supplementation during late gestation and early lactation was shown to prevent production losses in continuously milked (CM) multiparous cows (Annen et al., 2004a). Continuous milking, however, resulted in substantial production losses (13 to 20\%) in primiparous cows, even when supplemented with bST. Several studies have indicated that primiparous cows require a longer DP, possibly because of continued mammary development between the first and second lactation (Remond et al., 1992, 1997; Annen et al., 2004b). Others have attributed reductions in subsequent milk yield in CM (not bST-supplemented) multiparous cows to reduced MEC growth and functionality (Swanson et al., 1967; Capuco et al., 1997).

Although bovine prolactin and placental lactogen are known to increase mammary growth in late lactation, these molecules are not commercially available for use. Bovine somatotropin was found to increase mammary growth in late-gestation heifers (Collier, 2002), and bST slightly increased milk yield in early lactation (Bauman and Vernon, 1993). In addition, Hale and coworkers (2003) demonstrated that IMF increased milk yield and tended to increase mammary growth during early lactation. Although often inconsistent (VanBaale et al., 2005), others have reported marked increases in early- 
lactation milk yield while implementing IMF (BarPeled et al., 1995). In established lactation, both bST and IMF have known effects on 1) MEC synthetic activity, 2) the number of alveoli in a secretory and resting state, and 3) MEC numbers (Bauman and Vernon, 1993; Hale et al., 2003). During established lactation, the galactopoietic effects of bST and IMF are additive (Knight et al., 1992), and we hypothesize that these management practices may aid in minimizing or alleviating reduced milk yield in CM primiparous cows during early lactation.

The study objectives were to evaluate the effects of IMF and bST (Posilac, Monsanto Co., St. Louis, MO) on production and MEC proliferation and apoptotic variables in CM glands from primiparous cows. The study used a half-udder model to examine treatment effects in CM and 60-d dry (control) udder halves. The specific study objectives were to examine CM, bST, and IMF on 1) MEC proliferation, 2) MEC apoptosis, and 3 ) milk yield and composition.

\section{MATERIALS AND METHODS}

\section{Animal Selection Criteria}

The University of Arizona Institutional Animal Care and Use Committee approved all procedures involving animals. Cows were housed at the University of Arizona Agricultural Research Center in individual pens with ad libitum access to feed and water. At the beginning of the experiment, all cows were in good health and free of clinical mastitis, with SCC of less than 300,000.

\section{Prepartum Milking Procedures and Treatment Assignments}

A total of 8 primiparous cows (second gestation, first dry period) were assigned to a $2 \times 2 \times 2$ factorial study, using an ipsilateral, half-udder design. The half-udder treatments were either a $60-\mathrm{d}$ DP or CM during the last $60 \mathrm{~d}$ of gestation. Ipsilateral udder halves of each cow were randomly assigned to either a 60-d DP (control) or 0-d DP (CM). The whole-animal treatment was no bST (-bST; $0 \mathrm{mg} / 14 \mathrm{~d}$; $\mathrm{n}=4$ ) or continuous bST (+bST; $500 \mathrm{mg} / 14 \mathrm{~d} ; \mathrm{n}=4)$ during the DP and early postpartum period. The half-udder treatment (milking frequency) was $2 \times / d(n=4)$ or $4 \times / d(n=4)$ postpartum. Before parturition all CM half-udders were milked $2 \times /$ $\mathrm{d}$, and milk from each udder half was collected into separate buckets by using a unit designed to collect from all 4 quarters individually, but modified to collect milk from unilateral udder halves. Animals were milked for $7 \mathrm{~d}$ before treatment implementation to obtain a milk yield covariate and to confirm that udder halves produced equal amounts of milk. Any animal displaying more than a $10 \%$ difference in milk yield between udder halves was removed from the trial and replaced by an animal producing similarly (within a $10 \%$ difference) for both udder halves. The control udder half was dried after the morning milking $-60 \mathrm{~d}$ relative to the calculated parturition date and infused with a long-acting intramammary antibiotic (Quartermaster, West Agro Inc., Kansas City, MO).

\section{Spontaneous Dry-Off Protocol}

The CM udder half was milked throughout late gestation unless milk yield was below $5 \mathrm{~kg} / \mathrm{d}$ for 7 consecutive days. At this time, the udder half was considered to have spontaneously dried off. Average days dry for control udder halves were 59.5 and $49.3 \mathrm{~d}$ for the $+\mathrm{bST}$ and -bST treatment, respectively. In CM udder halves, a total of 3 dried off spontaneously ( $1+\mathrm{bST}, 2 \mathrm{~d}$, and 2 -bST, 4 and $26 \mathrm{~d}$ ). The dried-off udder half was then treated with a long-acting intramammary antibiotic, and milk removal ceased until parturition. Any cow that spontaneously dried off was fed the close-up diet (Table 1) until parturition.

\section{DMI}

Cows were offered ad libitum access to all diets used in the study (Table 1). Diets used during the study were formulated to meet or exceed NRC requirements (2001). Feed samples were obtained twice daily and dried at $100^{\circ} \mathrm{C}$, with one sample (including a.m. and p.m. feeding) per week randomly chosen and ground with a Wiley mill (model 3, Arthur H. Thomas Co., Philadelphia, PA). Daily dietary samples were obtained and combined into a weekly aliquot that was sent to Dairy One (Ithaca, NY) for dietary analyses (Table 1).

\section{Pre- and Postpartum Milking Protocols}

All cows on the $2 \times / \mathrm{d}$ protocol (prepartum and postpartum) were milked at 0400 and $1600 \mathrm{~h}$ and cows on the $4 \times / d$ regimen (postpartum) were milked at 0400, 0800, 1600 , and $2000 \mathrm{~h}$ for the first 30 DIM. Milk yield from each udder half was weighed and recorded after each milking, and weekly milk samples were obtained from each cow at the 0400 and $1600 \mathrm{~h}$ milking times. Each sample was component analyzed by Arizona DHIA (Tempe, AZ) by using AOAC (2000)-approved infrared analysis equipment and procedures.

\section{Mammary Biopsies}

Mammary biopsies were planned for $\mathrm{d}-20,-7,2,7$, and 20 relative to expected parturition. Because of the 
Table 1. Ingredients and chemical composition ${ }^{1}$ for close-up (3 wk before expected parturition) and lactating (d 1 through 30 postpartum) diets throughout the entire study

\begin{tabular}{lcc}
\hline Composition & Prepartum & Postpartum \\
\hline Ingredient, \% of DM & & \\
Alfalfa hay & 56.4 & 53.3 \\
Almond hulls & & 0.6 \\
Amino Plus $^{2}$ & 6.9 & 1.7 \\
Bermuda hay & 3.4 & 6.5 \\
Whole cottonseed & 19.3 & 16.4 \\
Steamed flaked corn & 10.7 & 4.1 \\
Molasses & & 7.9 \\
Dry citrus pulp & & 1.4 \\
Energy II & & 2.2 \\
Corn distillers grain & & 3.0 \\
Fat bran (15\% tallow) & 3.3 & 3.1 \\
Supplement & \\
Chemical analysis, \% of DM & 15.3 & 18.0 \\
CP & 56.7 & 40.3 \\
NDF & 43.9 & 25.2 \\
ADF & 0.74 & 0.79 \\
NE & Mcal/kg of DM &
\end{tabular}

${ }^{1}$ Values represent an average of samples collected and composited throughout trial. Dry matter averaged 65 and $51 \%$ for the prepartum and postpartum diets, respectively.

${ }^{2}$ Rumen-undegradable protein (Ag Processing Corp., Omaha, NE).

${ }^{3}$ Rumen-inert palm fatty acid distillate (Bioproducts Inc., Fairlawn, $\mathrm{OH})$.

${ }^{4}$ The prepartum supplement contained $7.8 \% \mathrm{Ca}, 8.0 \% \mathrm{P}, 11.5 \% \mathrm{Mg}$ $7.1 \% \mathrm{~S}, 0.3 \% \mathrm{~K}, 0.1 \% \mathrm{Na}, 24.6 \% \mathrm{Cl}, 1,788 \mathrm{mg} / \mathrm{kg}$ of $\mathrm{Zn}, 1,515 \mathrm{mg} / \mathrm{kg}$ of $\mathrm{Mn}, 691 \mathrm{mg} / \mathrm{kg}$ of $\mathrm{Fe}, 443 \mathrm{mg} / \mathrm{kg}$ of Cu, $59 \mathrm{mg} / \mathrm{kg}$ of Co, $12 \mathrm{mg} / \mathrm{kg}$ of Se, $5 \mathrm{mg} / \mathrm{kg}$ of Mo, $12 \mathrm{mg} / \mathrm{kg}$ of I, $549 \mathrm{IU} / \mathrm{g}$ of vitamin A, $67 \mathrm{IU} / \mathrm{g}$ of vitamin $\mathrm{D}$, and $7 \mathrm{IU} / \mathrm{g}$ of vitamin $\mathrm{E}$.

${ }^{5}$ The postpartum supplement contained $2.3 \% \mathrm{Ca}, 8.9 \% \mathrm{P}, 12.7 \%$ $\mathrm{Mg}, 1.4 \% \mathrm{~S}, 0.2 \% \mathrm{~K}, 21.7 \% \mathrm{Na}, 0.01 \% \mathrm{Cl}, 2,477.8 \mathrm{mg} / \mathrm{kg}$ of Zn, $2,094.2$ $\mathrm{mg} / \mathrm{kg}$ of Mn, $1,214.4 \mathrm{mg} / \mathrm{kg}$ of Fe, $686.3 \mathrm{mg} / \mathrm{kg}$ of Cu, $82.1 \mathrm{mg} / \mathrm{kg}$ of $\mathrm{Co}, 15.1 \mathrm{mg} / \mathrm{kg}$ of Se, $12.5 \mathrm{IU} / \mathrm{g}$ of vitamin D, and $0.9 \mathrm{IU} / \mathrm{g}$ of vitamin E.

variability in calving dates, actual mammary biopsy time points were $-19 \pm 13,-8 \pm 6,+2,+7$, and $+20 \mathrm{~d}$ relative to parturition. For each time point, tissue was obtained from both CM and control udder halves (either both front quarters or both rear quarters; alternating fore and rear between biopsy time points). Mammary gland biopsies were performed approximately $1 \mathrm{~h}$ after the morning milking, as previously described by Farr et al. (1996) and modified by Baumgard et al. (2002).

\section{Ki-67 Proliferation Assay}

Immunohistochemical localization of Ki-67 cell proliferation antigen, which determines the percentage of proliferating cells, was performed as described in Annen et al. (2007). Tissue sections for Ki67 were viewed by light microscopy and proliferating cells were quantified. By using an $8 \times 8$ ocular grid, 10 fields or 3,000 cells were quantified per slide for each biopsy time point, which included a control and a CM quarter slide ( 2 slides per time point per cow).

\section{Terminal Deoxynucleotide Transferase-Mediated 2 -Deoxyuridine 5'-Triphosphate Nick-End Labeling Assay}

Cells undergoing apoptosis were identified using terminal deoxynucleotide transferase-mediated 2'-deoxyuridine $5^{\prime}$-triphosphate nick-end labeling (TUNEL; ApoTag, Oncor, Gaithersburg, MD) as previously described by Annen et al. (2007).

Tissue sections for TUNEL were viewed by light microscopy, and apoptotic cells were quantified. By using an $8 \times 8$ ocular grid, 10 fields or 3,000 cells were quantified per slide for each biopsy time point, which included a control and a CM quarter slide ( 2 slides per time point per cow).

\section{Statistical Analyses}

Statistical analyses were performed with PROC MIXED in SAS (v. 8.2; SAS Institute, 1999). The level of significance was set at $P<0.05$ for main effects and interactions. For milk yield and composition analyses, data collected from both udder halves from d 67 to 61 prior to the expected parturition date were used as a covariate. The covariate was used because of yield and composition differences between udder halves within a cow before any treatments were applied. Time was fitted as a repeated measure by using a spatial power covariance structure. The variability among udder halves (nested within cow) within experiment cells was used to test the whole-plot effects of bST, milking frequency, dry period length, and their interactions. The variability among data for dependent variables within udder half (nested within cow) was used to test for the effects of time and interactions involving time.

Weekly milk means were obtained by averaging daily weights for each week and included milk yield from 10 wk prepartum until 4 wk postpartum. Milk composition was analyzed by using IMF, bST, DP length, week relative to parturition, and their possible interactions in the model. Milk composition from wk 2 postpartum was discarded from analyses because of blood contamination resulting from the +2 - and +7 - $d$ mammary biopsies. Mammary epithelial cell data for percentage of cells expressing the Ki67 antigen and percentage of MEC that had labeled free $3^{\prime}-\mathrm{OH}$ DNA termini were tested by using DP length, milking frequency, bST, day, and their potential interactions in the model. A covariate was not used for DMI, Ki67, and TUNEL data. Data from Ki67 and TUNEL assays were transformed (square root) to meet statistical assumptions for normal data distribution. Nontransformed data are presented in tables and figures because the outcome of statistical tests with transformed, and nontransformed data were equal. Additionally, linear SCS was calculated from 
Table 2. Summary of prepartum and postpartum milk yield in primiparous cows continuously milked (CM) or 60-d dry control udder halves, with or without bST supplementation, and milked either twice $(2 \times)$ or 4 times $(4 \times)$ daily from 1 through $30 \mathrm{~d}$ postpartum

\begin{tabular}{|c|c|c|c|c|c|}
\hline \multirow[b]{3}{*}{ Item } & \multicolumn{4}{|c|}{ Treatment $^{1}$} & \multirow[b]{3}{*}{ SE } \\
\hline & \multicolumn{2}{|c|}{ No bST } & \multicolumn{2}{|c|}{$\mathrm{bST}$} & \\
\hline & Control & $\mathrm{CM}$ & Control & $\mathrm{CM}$ & \\
\hline \multicolumn{6}{|l|}{$2 \times$ milking frequency } \\
\hline \multicolumn{6}{|l|}{ Prepartum } \\
\hline Half-udder milk yield, $\mathrm{kg} / \mathrm{d}$ & 0 & $8.2^{\mathrm{a}}$ & 0 & $10.3^{b}$ & 0.5 \\
\hline Postpartum & & & & & \\
\hline Half-udder milk yield, $\mathrm{kg} / \mathrm{d}$ & $22.3^{\mathrm{a}}$ & $10.9^{\mathrm{b}}$ & $22.4^{\mathrm{a}}$ & $10.1^{\mathrm{b}}$ & 1.6 \\
\hline \multicolumn{6}{|l|}{$4 \times$ milking frequency } \\
\hline \multicolumn{6}{|l|}{ Prepartum } \\
\hline Half-udder milk yield, $\mathrm{kg} / \mathrm{d}$ & 0 & 9.2 & 0 & 11.7 & 0.4 \\
\hline \multicolumn{6}{|l|}{ Postpartum } \\
\hline Half-udder milk yield, $\mathrm{kg} / \mathrm{d}$ & $21.5^{\mathrm{a}}$ & $13.9^{\mathrm{b}}$ & $24.3^{\mathrm{a}}$ & $16.0^{\mathrm{b}}$ & 2.5 \\
\hline
\end{tabular}

${ }^{\mathrm{a}, \mathrm{b}}$ Means within a row with different superscripts differ $(P<0.05)$.

${ }^{1}$ Means were adjusted by using data collected from d 67 to 61 prepartum as a covariate.

SCC to achieve normal distribution of the data. The SCS values were used for all statistical comparisons. Statistical analyses for prepartum parameters (milk yield and composition, MEC proliferation, apoptosis, and DMI) included 8 cows, whereas 7 cows were used in the postpartum parameter analyses (milk yield and composition, MEC proliferation and apoptosis, and DMI). One cow was removed because of a damaged vagal nerve, which ultimately resulted in her removal from the study on d 15 postpartum. Postpartum milk yield and DMI were not used (because of an excessive amount of missing data from her illness). The biopsy dates were deemed unaffected by this illness and biopsies were also taken before the onset of illness, except for the d-20 biopsy, so MEC proliferation and apoptosis indices were not used in the analyses for this cow on d 20 .

\section{RESULTS}

\section{Milk Production}

Prepartum. Prepartum ( -9 through -1 wk) half-udder milk yield was greater (Table $2 ; P<0.05$ ) in + bSTtreated cows milked $2 \times$ postpartum $(2.1 \pm 0.5 \mathrm{~kg})$ as well as those milked $4 \times$ postpartum $(2.5 \pm 0.4 \mathrm{~kg})$. Further details regarding the effects of bST on prepartum production variables can be found in Annen et al. (2007).

Postpartum. Regardless of the bST and IMF treatments, subsequent milk yield was reduced $(P<0.01)$ in CM halves compared with control udder halves (Table 2). When milking frequency was ignored, there was a numerical increase in whole-udder milk yield associated with the use of bST (34.3 vs. $36.4 \pm 2.1 \mathrm{~kg} / \mathrm{d}$ ) for -bST- and +bST-supplemented animals, respectively. When bST use was ignored, there was a numerical in- crease in milk yield associated with increasing milking frequency from $2 \times$ to $4 \times(32.9 \pm 1.6 \mathrm{~kg} / \mathrm{d}$ vs. $37.9 \pm 2.5$ $\mathrm{kg} / \mathrm{d}$; Table 2). Increased milking frequency and bST appeared to ameliorate the effects of $\mathrm{CM}$, because milk yield in $4 \times$ milked halves in cows receiving bST was $2.1 \pm 2.5 \mathrm{~kg} / \mathrm{d}$ greater than those milked $4 \times$ and not receiving bST (Table 2) and was $5.1 \pm 2.0 \mathrm{~kg} / \mathrm{d}$ more than cows milked $2 \times$ and not receiving bST (Table 2 ).

\section{Milk Composition}

Lactation status (CM or control), bST supplementation, and IMF $(2 \times$ vs. $4 \times)$ did not affect average milk protein $(3.0 \pm 0.1 \%)$, fat $(3.6 \pm 0.3 \%)$, lactose $(4.78 \pm$ $0.1 \%)$, or SCS $(2.5 \pm 1.0)$ for the first $30 \mathrm{~d}$ postpartum (data not shown).

\section{DMI}

Prepartum (wk -9 to -1 ) and postpartum (wk 1 to 4 ) DMI were not affected by bST supplementation (data not shown). Average postpartum DMI was 26.3 and 20.2 $\pm 2.0 \mathrm{~kg} / \mathrm{d}$ for $+\mathrm{bST}$ - and-bST-treated cows, respectively (data not shown).

\section{Mammary Proliferation (Ki67 Assay)}

Mean proliferation for all groups was higher on $\mathrm{d}-8$ $(4.14 \pm 0.56 \%)$ compared with $\mathrm{d}-20(2.35 \pm 0.56 \%$; Table $3)$. There was a tendency $(P=0.11)$ for greater MEC proliferation on d 8 and 20 prepartum in control tissue compared with CM tissue (Table 3). Mammary epithelial cell proliferation declined steadily in both groups from $-8 \mathrm{~d}$ prepartum to $20 \mathrm{~d}$ postpartum (Table 3 ). Overall, prepartum MEC proliferation was greater than postpartum MEC proliferation $(P<0.05$; Table 3$)$. 
Table 3. Changes in mammary epithelial cell proliferation and apoptosis during late gestation and early lactation in control (60-d dry) and continuously milked udder halves milked twice $(2 \times)$ or 4 times $(4 \times)$ daily during early lactation ${ }^{1}$

\begin{tabular}{|c|c|c|c|c|c|c|}
\hline \multirow[b]{2}{*}{ Item } & \multicolumn{6}{|c|}{ Day relative to parturition } \\
\hline & -20 & -8 & 2 & 7 & 20 & $\mathrm{SE}$ \\
\hline \multicolumn{7}{|l|}{$2 \times$ milking frequency } \\
\hline \multicolumn{7}{|l|}{ Ki67 antigen index, $\%$} \\
\hline Control & $2.28^{\mathrm{ay}}$ & $4.56^{\text {by }}$ & $1.17^{\mathrm{c}}$ & $0.67^{\mathrm{c}}$ & $0.35^{\mathrm{c}}$ & 0.50 \\
\hline $\mathrm{CM}$ & $3.74^{\mathrm{az}}$ & $2.70^{\mathrm{az}}$ & $1.04^{\mathrm{b}}$ & $0.46^{\mathrm{b}}$ & $0.27^{\mathrm{b}}$ & 0.49 \\
\hline \multicolumn{7}{|l|}{ Apoptotic index, \% } \\
\hline Control & $0.17^{\mathrm{a}}$ & $0.33^{\mathrm{ab}}$ & $0.56^{\mathrm{b}}$ & $0.67^{\text {bcy }}$ & $0.17^{\mathrm{a}}$ & 0.09 \\
\hline $\mathrm{CM}$ & $0.16^{\mathrm{a}}$ & $0.20^{\mathrm{a}}$ & $0.80^{\mathrm{b}}$ & $0.27^{\mathrm{az}}$ & $0.20^{\mathrm{a}}$ & 0.09 \\
\hline $4 \times$ milking frequency ${ }^{2}$ & -20 & -8 & 2 & 7 & 20 & $\mathrm{SE}$ \\
\hline \multicolumn{7}{|l|}{ Ki67 antigen index, \% } \\
\hline Control & $2.37^{\mathrm{a}}$ & $6.08^{\mathrm{a}}$ & $1.08^{\mathrm{b}}$ & $0.30^{\mathrm{b}}$ & $0.26^{\mathrm{b}}$ & 0.61 \\
\hline $\mathrm{CM}$ & $1.33^{\mathrm{a}}$ & $3.21^{\mathrm{a}}$ & $0.30^{\mathrm{b}}$ & $0.11^{\mathrm{b}}$ & $0.23^{\mathrm{b}}$ & 0.65 \\
\hline \multicolumn{7}{|l|}{ Apoptotic index, \% } \\
\hline Control & $0.29^{\mathrm{a}}$ & $0.32^{\mathrm{a}}$ & $1.38^{\mathrm{b}}$ & $1.81^{\mathrm{b}}$ & $0.41^{\mathrm{a}}$ & 0.45 \\
\hline $\mathrm{CM}$ & $0.44^{\mathrm{a}}$ & $0.47^{\mathrm{a}}$ & $2.09^{b}$ & $1.08^{\mathrm{b}}$ & $0.14^{\mathrm{a}}$ & 0.46 \\
\hline
\end{tabular}

${ }^{\mathrm{a}-\mathrm{c} W i t h i n ~ a ~ t r e a t m e n t ~(r o w) ~ d i f f e r e n c e s ~ o v e r ~ t i m e ~ a r e ~ i n d i c a t e d ~ b y ~ d i f f e r e n t ~ s u p e r s c r i p t s ~}(P<0.05)$.

${ }^{\mathrm{y}, \mathrm{z}}$ Differences between treatments are indicated by different superscripts $(P<0.05)$.

${ }^{1}$ No effect of bST was detected for the Ki67 antigen index or apoptotic index $(P>0.05)$. The Ki67 antigen index was not altered by milking frequency, but the apoptotic index was increased $(P<0.05)$ by $4 \times$ milking.

${ }^{2}$ Within $4 \times$ milking frequency, a late-gestation lactation status (control vs. $\left.\mathrm{CM}\right) \times$ day interaction was not detected for the Ki67 antigen or apoptotic indices.

During the postpartum period, MEC proliferation was greater in $2 \times$ milked glands (Annen et al., 2007) than in $4 \times$ milked glands $(P<0.05$; Table 3$)$.

\section{Mammary Apoptosis (TUNEL Assay)}

Apoptosis in cells was affected by time $(P<0.01)$ and milking frequency $(P<0.01$; Table 3$)$. Although $2 \times$ and $4 \times$ milked cows displayed a similar temporal pattern of MEC apoptosis, $4 \times$ milked cows had an overall greater number of apoptotic MEC during the postpartum period $(P<0.01$, d 2, 7, and 20; Table 3). Overall apoptosis peaked on $\mathrm{d} 2$ postpartum in control udder halves for the $2 \times$ cows, and $4 \times$ cows displayed more apoptotic events in $\mathrm{CM}$ udder halves on $\mathrm{d} 2$. Apoptosis was numerically greater in the CM $4 \times$ udder halves compared with CM $2 \times$ udder halves on $d 2$ and $7(P=0.12$; Table 3$)$, but CM $4 \times$ udder halves were numerically lower than CM $2 \times$ udder halves on d $20(P=0.15$; Table 3$)$. Neither lactation status (CM vs. control) nor bST (pre- or postpartum period) affected MEC apoptosis events.

\section{DISCUSSION}

\section{Milk Production Parameters}

The use of a half-udder model to estimate effects of CM could potentially influence the dried-off half because of oxytocin and other hormones released with each milking of the treated half. If there were any such effects in this study, it would have to be concluded that they were positive, because the milk yield differences between dried-off and CM halves postpartum were larger than expected (34 to 36\%) in early lactation of the subsequent lactation, and this was not prevented by bST supplementation or IMF. In fact, early-lactation production losses were even greater than previously reported from bST-supplemented primiparous cows (13 to $20 \%$; Annen et al., 2004a). In a study conducted simultaneously, however, we reported a $53 \%$ reduction in subsequent milk yield in CM udder halves from primiparous cows, regardless of bST treatment (Annen et al., 2007). The absence of a milk yield response to bST in early lactation is not surprising because recombinant bST responses are typically much less in early lactation compared with those in established lactation (Bauman and Vernon, 1993). This is likely due to the negative energy balance and an uncoupling of the somatotropic axis in early-lactation cows (Vicini et al., 1991), because it is well known that bST is less effective while the somatotropic axis is partially or completely uncoupled (McGuire et al., 1995).

We hypothesized that galactopoietics would stimulate MEC growth in CM tissue to compensate for reductions in MEC growth caused by CM during late gestation and would result in production levels equal or similar to the control halves. When data were compared with the $2 \times$ results in our companion study (Annen et al., 2007), IMF may have alleviated a small part of the production losses (numerically) in the CM halves (35 vs. 53\%). Nonetheless, production losses were dramatic 
and lend support to other data demonstrating that $\mathrm{CM}$ is not a viable management practice for primiparous cows (Remond et al., 1992, 1997; Annen et al., 2004b). In addition, $4 \times$ milking did not increase milk yield ( 1 through 30 DIM) in control halves when compared with the $2 \times$ milking control data of Annen et al. (2007; 44.4 vs. $65.9 \mathrm{~kg}$ ). Hale et al. (2003) reported that early-lactation IMF increased milk yield by $8.8 \mathrm{~kg} / \mathrm{d}$, whereas in the current study $4 \times$ milking did not influence milk yield ( 33.9 vs. $35.4 \mathrm{~kg} / \mathrm{d}$ ). Others have failed to detect an effect of IMF during early lactation in dairy cattle (VanBaale et al., 2005). Reasons for the lack of IMF effects are not apparent. The CM glands milked $4 \times$ and supplemented with bST seemed to have less severe production losses than the CM glands milked $2 \times$ and supplemented with bST ( -34 vs. $-56 \%)$.

\section{Milk Composition}

Milk composition was not affected by bST or DP length. Regardless of bST treatment or DP length, both the control and CM udder halves maintained normal fat and protein production. Additionally, udder health (as indicated by low SCS) was maintained in CM and control halves throughout the study.

\section{Mammary Proliferation and Apoptosis}

Apoptosis. Apoptosis rates across all treatments were higher in the early postpartum period ( $\mathrm{d} 2$ and 7) compared with late gestation and d 20 postpartum ( $P$ $<0.05$ ). This suggests that older senescent cells that are carried over from the previous lactation may be vulnerable to removal early in the next lactation. It has been suggested that apoptosis may be equally as responsible as MEC proliferation in regulating mammary growth and mediating the effects of IMF on milk yield (Bar-Peled et al., 1995; Capuco et al., 2003; Hale et al., 2003). Therefore, we expected that IMF would lower the apoptotic index across treatments. Contrary to this hypothesis, data from the current study and our earlier work (Annen et al., 2007) indicated a trend for greater apoptotic rates $(0.72 \%)$ in control halves milked $4 \times$ compared with control halves milked $2 \times(0.54 \%)$, and a similar trend in CM halves ( 0.60 vs. $0.22 \%$, respectively). Additionally, IMF prevented the premature decrease in early lactation of MEC removal, which was previously observed at d 7 postpartum by Annen et al. (2007). It may be that IMF stimulates increased removal of resting MEC, which has been shown in ultrastructure data in cows milked $2 \times$ (Annen et al., 2007) to be greater in CM tissue at $20 \mathrm{~d}$ postpartum. Increased shedding may enable atrophy of older, resting MEC and potentially increase the synthetic capacity of newer cell populations (Sorensen et al., 2006). Increased MEC shedding in the current study did not result in milk yields greater than those of $2 \times$ glands in our companion study.

\section{CONCLUSIONS}

We hypothesized that IMF would enhance mammary growth and also prevent apoptosis in CM glands. Furthermore, we anticipated that MEC proliferation would be greater in more frequently milked glands and that this enhanced growth would improve milk yield in CM udder halves. However, we failed to prevent a milk yield decrease or to show an increase in proliferation. Reduction in milk yield of CM half udders in cows administered bST and milked $4 \times$ was $35 \%$ compared with a $65 \%$ reduction in yield in CM half udders of cows not given bST and milked $2 \times$. In summary, CM reduced mammary growth and postpartum MEC functionality in primiparous cows. Mammary growth was not improved by using bST and IMF in primiparous cows. Mammary epithelial cell proliferation was greatest in all groups (CM or control, $2 \times$ or $4 \times$ glands) in the prepartum period.

\section{REFERENCES}

Annen, E. L., R. J. Collier, M. A. McGuire, and J. L. Vicini. 2004a. Effect of dry period length on milk yield and mammary epithelial cells. J. Dairy Sci. 87(E Suppl.):E66-E76.

Annen, E. L., R. J. Collier, M. A. McGuire, J. L. Vicini, J. M. Ballam, and M. J. Lormore. 2004b. Effect of modified dry period lengths and bovine somatotropin on yield and composition of milk from dairy cows. J. Dairy Sci. 87:3746-3761.

Annen, E. L., A. C. Fitzgerald, P. C. Gentry, M. A. McGuire, A. V. Capuco, L. H. Baumgard, and R. J. Collier. 2007. Effect of continuous milking and bST supplementation on mammary epithelial cell turnover. J. Dairy Sci. 90:165-183.

Bachman, K. C., and M. L. Schairer. 2003. Invited review: Bovine studies on optimal lengths of dry periods. J. Dairy Sci. 86:3027-3037.

Bar-Peled, U., E. Maltz, I. Bruckental, Y. Folman, Y. Kali, H. Gacitua, A. R. Lehrer, C. H. Knight, B. Robinson, and H. Voet. 1995. Relationship between frequent milking or suckling in early lactation and milk production of high producing dairy cows. J. Dairy Sci. 78:2726-2736.

Bauman, D. E., and R. G. Vernon. 1993. Effects of exogenous bovine somatotropin on lactation. Annu. Rev. Nutr. 13:437-461.

Baumgard, L. H., E. Matitashvili, B. A. Corl, D. A. Dwyer, and D. E. Bauman. 2002. Trans-10, cis-12 conjugated linoleic acid decreases lipogenic rates and expression of genes involved in milk lipid synthesis in dairy cows. J. Dairy Sci. 85:2155-2163.

Capuco, A. V., R. M. Akers, and J. J. Smith. 1997. Mammary growth in Holstein cows during the dry period: Quantification of nucleic acids and histology. J. Dairy Sci. 80:477-487.

Capuco, A. V., S. E. Ellis, S. A. Hale, E. Long, R. A. Erdman, X. Zhao, and M. J. Paape. 2003. Lactation persistency: Insights from mammary cell proliferation studies. J. Anim. Sci. 81(Suppl. 3):18-31.

Collier, R. J. 2002. Metabolic modifiers: Advances in economic production of safe food. Pages 26-31 in Scientific Advances in Animal Nutrition: Promise for the New Century. Symp. Proc. Natl. Acad. Press, Washington, DC. 
Collier, R. J., L. H. Baumgard, A. L. Lock, and D. E. Bauman. 2005. Physiological limitations: Nutrient partitioning. Pages 351-377 in Yields of Farmed Species: Constraints and Opportunities in the 21st century. Proc. 61st Eastern School Nottingham, England. J. Wiseman and R. Bradley, ed. Nottingham Univ. Press, Nottingham, UK.

Farr, V. C., K. Stelwagen, L. R. Cate, A. J. Molenaar, T. B. McFadden, and S. R. Davis. 1996. An improved method for the routine biopsy of bovine mammary tissue. J. Dairy Sci. 79:543-549.

Hale, S. A., A. V. Capuco, and R. A. Erdman. 2003. Milk yield and mammary growth effects due to increased milking frequency during early lactation. J. Dairy Sci. 86:2061-2071.

Knight, C. H., J. E. Hillerton, M. A. Kerr, R. M. Teverson, A. Turvey, and C. J. Wilde. 1992. Separate and additive stimulation of bovine milk yield by the local and systemic galactopoietic stimuli of frequent milking and growth hormone. J. Dairy Res. 59:243-252.

McGuire, M. A., D. E. Bauman, D. A. Dwyer, and W. S. Cohick. 1995. Nutritional modulation of the somatotropin/insulin-like growth factor system: Response to feed deprivation in lactating cows. J. Nutr. 125:493-502.

Remond, B., J. Kérouanton, and V. Brocard. 1997. Effects de la reduction de la durée de la période séche ou de son omission sur les performances des vaches laitiéres. Prod. Anim. 10:301-333.
Remond, B., A. Ollier, and G. Miranda. 1992. Milking of cows in late pregnancy: Milk production during this period and during the succeeding lactation. J. Dairy Res. 59:233-241.

SAS Institute. 1999. SAS User's Guide. Statistics, Version 8.0 ed. SAS Inst. Inc., Cary, NC.

Sorensen, M. T., J. V. Norgaard, P. K. Theil, M. Vestergaard, and K. Sejrsen. 2006. Cell turnover and activity in mammary tissue during lactation and the dry period in dairy cows. J. Dairy Sci. 89:4632-4639.

Swanson, E. W., F. E. Pardue, and D. B. Longmire. 1967. Effect of gestation and dry period of deoxyribonucleic acid and alveolar characteristics of bovine mammary glands. J. Dairy Sci. 50:1288-1292.

VanBaale, M. J., D. R. Ledwith, J. M. Thompson, R. Burgos, R. J. Collier, and L. H. Baumgard. 2005. Effect of increased milking frequency in early lactation with or without recombinant bovine somatotropin. J. Dairy Sci. 88: 3905-3912.

Vicini, J. L., F. C. Buonomo, J. J. Veenhuizen, M. A. Miller, D. R. Clemmons, and R. J. Collier. 1991. Nutrient balance and stage of lactation affect responses of insulin, insulin-like growth factors I and II, and insulin-like growth factor-binding protein 2 to somatotropin administration in dairy cows. J. Nutr. 121:1656-1664. 